\title{
NEOLITHIC MASSACRES: LOCAL SKIRMISHES OR GENERAL WARFARE IN EUROPE?
}

\author{
Eva Maria Wild ${ }^{1}$ Peter Stadler ${ }^{2} \cdot$ Annemarie Häußer $^{3} \cdot$ Walter Kutschera ${ }^{1}$ Peter Steier ${ }^{1} \bullet$ \\ Maria Teschler-Nicola ${ }^{4}$ Joachim Wahl $^{5} \bullet$ Helmut J Windl ${ }^{6}$
}

\begin{abstract}
The Neolithic site of Schletz in Lower Austria comprises a fortified settlement from the end of the Linearbandkeramik (LBK) culture. Large numbers of human bones were found at the base of the fortification ditches, and many of the excavated bones and skulls showed evidence of trauma which most likely originates from violence. This remarkable deposit of human remains has been considered evidence for an abrupt end to the Early Neolithic settlement at Schletz. In order to investigate this interpretation, radiocarbon accelerator mass spectrometry (AMS) measurements of human bone samples from this site were performed at VERA. The $\chi^{2}$ test of the results from specimens with clearly identified lesions suggests that these may be contemporaneous. Further, it may be concluded that all individuals with evidence of trauma from Schletz were probably the victims of a single event: a massacre at the end of the LBK.
\end{abstract}

Similar evidence is found at Early Neolithic sites at Talheim and Herxheim in the western part of Germany. Analysis of the ${ }^{14} \mathrm{C}$ ages of bones from both sites suggests that the Talheim event may have been coeval with the massacre of Schletz, whereas an event at Herxheim might have happened some time earlier. For Herxheim, the massacre theory is still under discussion, and a change in the burial rite is also considered as an alternative interpretation.

\section{INTRODUCTION}

The Linearbandkeramik (LBK) is a European culture which developed in the central part of Europe in Early Neolithic times. This culture was spread over a large area of Europe, from the northwestern regions of Germany to the southeastern parts of Europe around the Black Sea. In contrast to all succeeding cultures, the LBK rarely showed local characteristics in ceramic styles. People of the LBK lived in the period after the fundamental transition in human lifestyle from hunter-gathering to farming. Generally, the LBK time is considered to have been a peaceful period (Petrasch 1999). At the end of the LBK, though, living conditions must have become more violent, seen by the occurrence of settlements with fortifications.

\section{THE EARLY NEOLITHIC SITE AT SCHLETZ IN LOWER AUSTRIA}

One of the fortified settlements from the end of the LBK period is the archaeological site at Schletz in eastern Austria. Schletz is located about $50 \mathrm{~km}$ north of Vienna in Lower Austria (Figure 1a). A map of the settlement, derived from aerial survey and geophysical investigations, is given in Figure $1 b$. The 2 oval fortification ditches of the settlement are indicated. Systematic excavations at the site started in 1983 and are still on-going (Windl 1996, 2001).

\footnotetext{
${ }^{1}$ Vienna Environmental Research Accelerator (VERA), Institut für Isotopenforschung und Kernphysik, Universität Wien, Währinger Strasse 17, A-1090 Wien, Austria. Corresponding author. Email: eva.maria.wild@univie.ac.at.

${ }^{2}$ Prähistorische Abteilung, Naturhistorisches Museum, Burgring 7, A-1014 Wien, Austria.

${ }^{3}$ Landesamt f. Denkmalpflege, Amt Speyer, Kleine Pfaffengasse 10, D-67345 Wiesbaden, Germany.

${ }^{4}$ Anthropologische Abteilung, Naturhistorisches Museum, Burgring 7, A-1014 Wien, Austria.

${ }^{5}$ Landesdenkmalamt Baden-Württemberg, Osteologie, Stromeyersdorfstraße 3, D-78467 Konstanz, Germany.

${ }^{6}$ Museum für Urgeschichte des Landes Niederösterreich, A-2151 Asparn/Zaya, Austria.
}

(C) 2004 by the Arizona Board of Regents on behalf of the University of Arizona Proceedings of the 18th International Radiocarbon Conference, edited by N Beavan Athfield and R J Sparks RADIOCARBON, Vol 46, Nr 1, 2004, p 377-385 

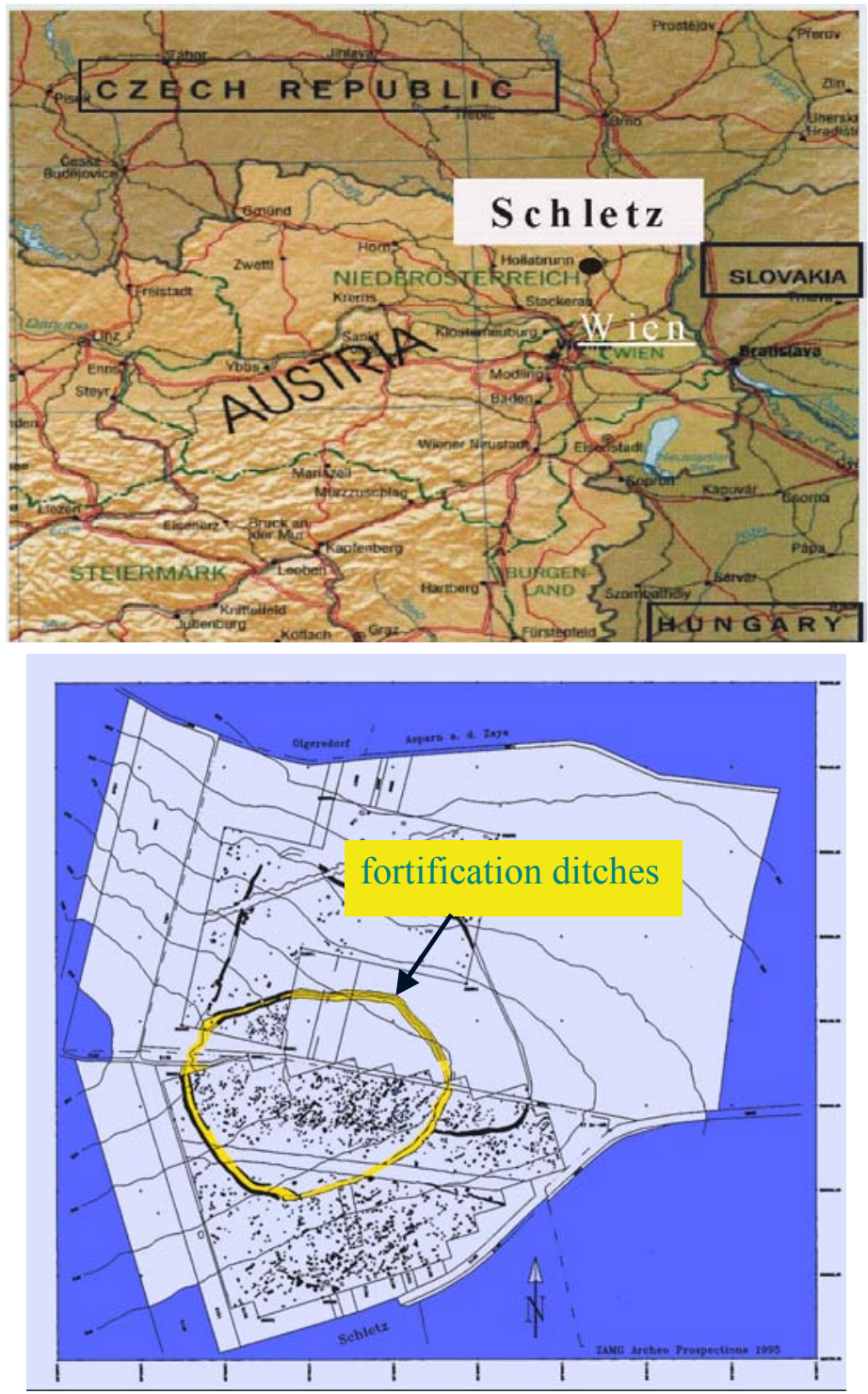

Figure 1 (a) Map of the northeastern part of Austria showing the location of Schletz, north of Vienna; (b) Map of the Early Neolithic site of Schletz derived from aerial survey and geophysical prospection (Windl 1996).

\section{Anthropologic Investigations of Human Remains from Schletz}

In the course of the excavations at Schletz, large numbers of human remains were found at the base of the outer ditch. It is estimated from the number of cranial and postcranial remains that approximately 200 individuals were deposited in the ditches. Up to now, about 100 individuals have been excavated. The skeletons were found mainly in strange positions, and often several skeletons were grouped together (see Figure 2). The bodies were deposited prone and many skeletons were incomplete with extremities missing. 


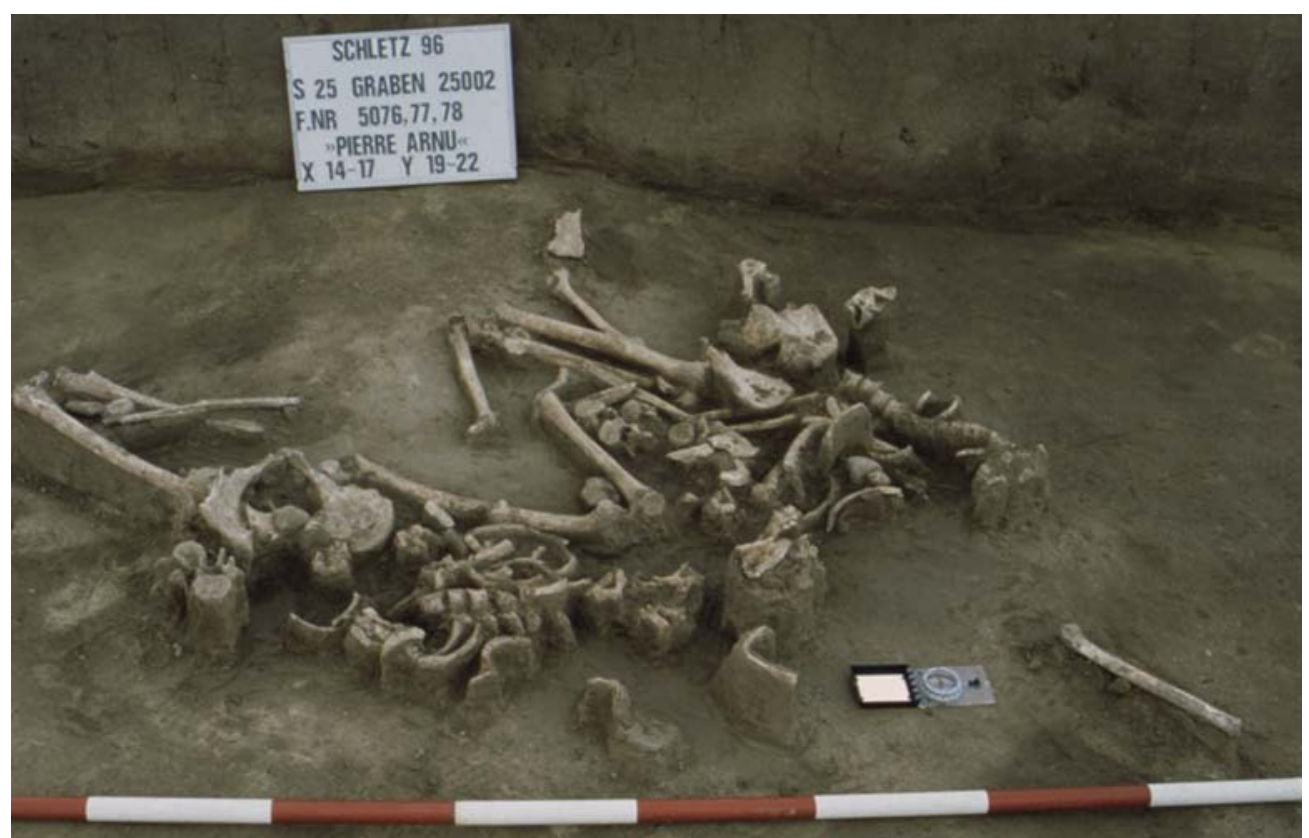

Figure 2 Photograph from the Early Neolithic excavation area at Schletz showing human remains as found in the fortification ditches.

A subsample of 67 individuals has been investigated by osteologists. This investigation showed that all the skulls were lethally fractured (Figure 3), and many of the postcranial remains exhibit unusual features too. A large number of the bones showed carnivore gnawing marks. The age and the sex distribution of the individuals was also determined, and it is evident that the occurrence of females among the young adult population is significantly reduced. From these results, it has been suggested that the traumatic lesions originate from inter-human aggressive acts. It was also suggested that the carnivore bite marks, which are definitely post-mortem alterations of the bones, indicate that the individuals were left unburied for some time. The reduced abundance of females amongst the young adults was interpreted as an indication of the abduction of women of child-bearing age. It was further deduced that these humans were probably the victims of a massacre which led to the abrupt end of the LBK settlement at Schletz (Teschler-Nicola et al. 1999).

\section{Other European Early Neolithic Sites with Evidence of Massacre}

A similar situation as in Schletz is also found at 2 Neolithic sites from the LBK period in Germany: at Herxheim in Rheinland-Pfalz and in Talheim near Heilbronn in Baden-Württemberg. These 2 sites are located approximately $750 \mathrm{~km}$ to the northwest and $660 \mathrm{~km}$ to the west from Schletz, respectively.

\section{Talheim}

The remains of 34 human individuals were excavated from a mass grave found at Talheim in 1983/ 84. This mass grave was located outside the (assumed) settlement area, which was detected by a surveying project more than $50 \mathrm{yr}$ ago. In contrast to Schletz, no fortifications have yet been found. The position of the skeletons indicated that these human remains were not buried according to usual LBK burial rites. Many bodies were lying face down, others in a very unusual twisted posture, and 


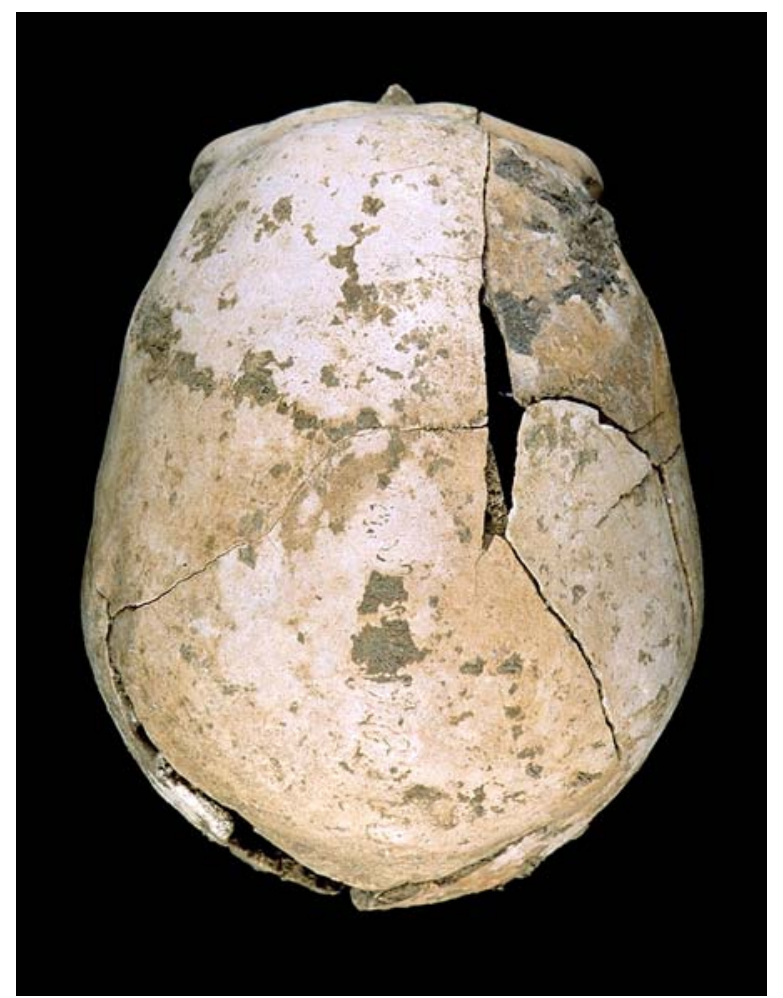

Figure 3 Human skull excavated at Schletz with a typical bending fracture

several skeletons were mixed together. In contrast to the Schletz remains described above, animal gnawing marks were not found. The whole assemblage was interpreted as a mass grave, with bodies quickly thrown into a pit and covered. Anthropological investigation of the bones showed that several skulls were lethally fractured. This again suggests that the humans found in the mass grave were the victims of a massacre. A possible deficit of infants in the age group of below $4 \mathrm{yr}$ was suggested from the age and sex profile of the burial assemblage. It was calculated from the number of women of child-bearing age that no more than 4 additional children should have been present in the grave. Three reasons were considered for the possibility of missing infants: the new-born children may have died of natural causes before the massacre and been buried according to usual custom; the average time between pregnancies could have been almost doubled by nutrition deficiencies and/or physical, plus psychological stress of the women; and third, that these children have been kidnapped by the attackers (Wahl and König 1987).

\section{Herxheim}

In the Herxheim area, archaeological finds are known since 1900. Up to now, more than 75 sites have been detected. Early excavations showed that they date from the Hallstatt and the La Tène periods and also from the Neolithic. In a big excavation campaign in 1996-1999, a large LBK settlement was excavated. The settlement was equipped with an outer and an inner fortification ditch-similar to Schletz - where a huge amount of human remains was found. It has been estimated from the excavated bones that more than 500 individuals are buried/deposited in the excavation area, most of them in the ditches (Häußer 1998). Many skeletons were incomplete and were not lying in a correct 
anatomical position. Several bones were fragmented and deposited together with animal bones, pottery, and other waste material from the settlement. The most extraordinary findings at Herxheim are calottes from human skulls which at some places appeared to be grouped together. Also, cut marks have been detected on some skulls and bones. For the Herxheim site, a massacre is not the only reason put forward for the atypical burial of the human remains. It is also suggested that these remains may be the result of a change in burial rites at the end of the LBK (Orschiedt 2003; Häußer 1998).

\section{${ }^{14} \mathrm{C}$ DATING AND DATA EVALUATION}

In order to test the hypothesis that people were killed at the same time, 15 human bone samples from Schletz were ${ }^{14} \mathrm{C}$ dated at the Vienna Environmental Research Accelerator (VERA).

The dated bones originated from the fortification ditches as well as from regular graves within the settlement. Our standard procedures for the preparation of bone samples and the ${ }^{14} \mathrm{C}$ measurement protocol which we use for archaeological samples were also applied for the Schletz samples (Wild et al. 1998, 2001).

The age determinations are listed in Table 1, together with information on whether the sample originates from a massacred individual or an individual buried in a grave. Two bone samples from Schletz excavated from the ditches were dated some years ago at ETH Zurich. The ${ }^{14} \mathrm{C}$ ages of $6145 \pm 55$ BP (ETH 14373) and $6025 \pm 55$ BP (ETH 14374) were determined by accelerator mass spectrometry (AMS). From the entire data set (VERA plus ETH data), the unrounded results from samples with clearly identified trauma were combined. The sample from the ditch with the anthropological assessment "massacre not proved" was not included. A $\chi^{2}$ test of the selected data was performed to check whether the distribution of the results is in agreement with the hypothesis that all samples are of the same age (e.g. Geyh and Schleicher 1990). After the removal of 1 outlier (VERA-2020/VERA-2738, see Table1), a $\chi^{2}$ value of 15.4 at 10 degrees of freedom (df) was calculated. The age determination of sample VERA-2020 was repeated (VERA-2738) and the age is in agreement with the result of the first measurement. The outlying of this sample is unexplained. Usually, for the rejection of the "Null hypothesis" (in the present case: all dated samples are coeval), a $5 \%$ significance level is used. For a data set with $10 \mathrm{df}$, a $\chi^{2}$ value of 18.3 corresponds to the $5 \%$ significance level. As the $\chi^{2}$ value determined for the measured data set is smaller than this, the Null hypothesis $\left(\mathrm{H}_{0}\right.$ in statistical textbooks) can be accepted, i.e., no significant differences between the sample ages have been detected. The Schletz data suggest that the samples may originate from the same time. This result seems to support the massacre theory. In addition, no regular grave was dated (see Table 1) to be younger than the time of the massacre. Thus, the massacre could have been the cause of the end of the Neolithic settlement at Schletz.

Human bones from the 2 German sites were also dated at VERA: 4 samples from Herxheim and 7 samples from Talheim (Table 2). The respective data sets were combined and again $\chi^{2}$ tests were performed. Two samples from Talheim were ${ }^{14} \mathrm{C}$ dated in the 1980 s by GPC (gas proportional counting) at Heidelberg. Sample HD 8606-8827, gave a ${ }^{14} \mathrm{C}$ age of $5960 \pm 80 \mathrm{BP}$, and for sample $\mathrm{HD} 8607-8828, \mathrm{a}{ }^{14} \mathrm{C}$ age of $6045 \pm 80 \mathrm{BP}$ was determined. Although consistent with the AMS ${ }^{14} \mathrm{C}$ ages determined at VERA, these results were not included in the present study because of the relatively large uncertainty on these ages. Adding these data to the AMS data set does not have a significant effect on the result of the weighted mean or on the result of the $\chi^{2}$ test.

According to the $\chi^{2}$ value of 1.5 (required value for the rejection of $\mathrm{H}_{0}$ at a $5 \%$ significance level and 3 df: 7.8) determined for the Herxheim data, no deviation from the contemporaneity of the investigated samples is detected. One outlier (VERA-2021, see Table 2) had to be rejected from the Tal- 
Table $1{ }^{14} \mathrm{C}$ data (rounded off according to Stuiver and Polach 1977) of all bone samples from Schletz measured at VERA and ETH Zurich.

\begin{tabular}{|c|c|c|c|c|c|c|}
\hline${ }^{14} \mathrm{C}$ lab nr & $\begin{array}{l}\text { Sample } \\
\text { material }\end{array}$ & $\begin{array}{l}\text { Find inventory nr, } \\
\text { provenance, and } \\
\text { anthroplogical assessment }\end{array}$ & $\begin{array}{l}\text { Individual } \\
\mathrm{nr}\end{array}$ & $\begin{array}{l}\delta^{13} \mathrm{C}^{\mathrm{a}} \\
{[\% 0]}\end{array}$ & $\begin{array}{l}{ }^{14} \mathrm{C} \text { age }{ }^{\mathrm{a}} \\
{[\mathrm{BP}]}\end{array}$ & $\begin{array}{l}\text { Calibrated time range }{ }^{\mathrm{b}} \\
2 \sigma \text { confidence interval }\end{array}$ \\
\hline VERA-2007 & human bone & $\begin{array}{l}44704224^{c}, \text { ditch, } \\
\text { probably massacred }\end{array}$ & $1993 / 12$ & $-21.7 \pm 0.4$ & $6175 \pm 35$ & $5260 \mathrm{BC}(95.4 \%) 4990 \mathrm{BC}$ \\
\hline VERA-2008 & human bone & 4518, ditch, massacred & $1993 / 5$ & $-23.9 \pm 0.5$ & $6145 \pm 35$ & $\begin{array}{l}5260 \mathrm{BC}(25.0 \%) 5160 \mathrm{BC} \\
5150 \mathrm{BC}(70.4 \%) 4940 \mathrm{BC}\end{array}$ \\
\hline VERA-2009 & human bone & 4518, ditch, massacred & $1993 / 4$ & $-21.5 \pm 0.6$ & $6055 \pm 35$ & $\begin{array}{l}5050 \mathrm{BC}(93.1 \%) 4840 \mathrm{BC} \\
4820 \mathrm{BC}(2.3 \%) 4800 \mathrm{BC}\end{array}$ \\
\hline VERA-2010 & human bone & $4520^{\mathrm{d}}$, ditch, massacred & $1993 / 2$ & $-20.5 \pm 0.5$ & $6130 \pm 35$ & $\begin{array}{l}5230 \mathrm{BC}(18.4 \%) 5160 \mathrm{BC} \\
5150 \mathrm{BC}(75.7 \%) 4940 \mathrm{BC} \\
4870 \mathrm{BC}(1.2 \%) 4860 \mathrm{BC}\end{array}$ \\
\hline VERA-2011 & human bone & $4520^{\mathrm{d}}$, ditch, massacred & $1993 / 17$ & $-21.1 \pm 0.5$ & $6100 \pm 35$ & $\begin{array}{l}5210 \mathrm{BC}(7.0 \%) 5170 \mathrm{BC} \\
5140 \mathrm{BC}(1.8 \%) 5120 \mathrm{BC} \\
5080 \mathrm{BC}(81.2 \%) 4900 \mathrm{BC} \\
4880 \mathrm{BC}(5.4 \%) 4850 \mathrm{BC}\end{array}$ \\
\hline VERA-2012 & one & red & $1996 / 3$ & $-22.4 \pm 0.6$ & 35 & $\begin{array}{l}5200 \mathrm{BC}(1.2 \%) 5180 \mathrm{BC} \\
5070 \mathrm{BC}(81.1 \%) 4900 \mathrm{BC} \\
4890 \mathrm{BC}(13.1 \%) 4840 \mathrm{BC}\end{array}$ \\
\hline VERA-2737 & one & 6076' $6^{\mathrm{c}}$ ditch, & $1997 / 4$ & $-19.3 \pm 0.4$ & $6175 \pm 30$ & $\begin{array}{l}5260 \mathrm{BC}(93.7 \%) 5030 \mathrm{BC} \\
5020 \mathrm{BC}(1.7 \%) 5000 \mathrm{BC}\end{array}$ \\
\hline VERA-2014 & human bone & 685/S11, ditch, massacred & Ind. 41 & $-21.1 \pm 0.5$ & $6125 \pm 35$ & $\begin{array}{l}5230 \mathrm{BC}(16.4 \%) 5160 \mathrm{BC} \\
5150 \mathrm{BC}(77.2 \%) 4930 \mathrm{BC} \\
4880 \mathrm{BC}(1.8 \%) 4850 \mathrm{BC}\end{array}$ \\
\hline VER & & & & -20 & & $5260 \mathrm{BC}(95.4 \%) 4960 \mathrm{BC}$ \\
\hline VERA-2016 & e & ar grave & Ind. 24 & $-18.9 \pm 0.5$ & $6210 \pm 40$ & $5300 \mathrm{BC}(95.4 \%) 5050 \mathrm{BC}$ \\
\hline VERA & one & $\begin{array}{l}264 / \mathrm{S} 4-6 \text {, ditch, massacre } \\
\text { not proved }\end{array}$ & Ind. 62 & $-21.8 \pm 0.4$ & $6200 \pm 35$ & $5300 \mathrm{BC}(95.4 \%) 5040 \mathrm{BC}$ \\
\hline VERA-2019 & & ovenance & & $-21.8 \pm 0.6$ & \pm 40 & $5280 \mathrm{BC}$ \\
\hline & & & & & & $0 \mathrm{BC}$ \\
\hline VER & human bone & $\begin{array}{l}\text { 4455, ditch, massac } \\
\text { VERA-2020 repeat }\end{array}$ & 1993/11 & $-20.5 \pm 0.5$ & $6205 \pm 30$ & 4\%) $5050 \mathrm{BC}$ \\
\hline VER & & 666 , regular grave & - & -18 & & $0 \mathrm{BC}$ \\
\hline & & rave & - & & & \%) $4990 \mathrm{BC}$ \\
\hline & & & n.a. ${ }^{\mathrm{e}}$ & & & $5060 \mathrm{BC}(95.4 \%) 4770 \mathrm{BC}$ \\
\hline ETH 14374 & human bone & 4521, ditch, massacred & n.a. & $-20.6 \pm 1.2$ & $6145 \pm 55$ & $\begin{array}{l}5280 \mathrm{BC}(93.7 \%) 4910 \mathrm{BC} \\
4880 \mathrm{BC}(1.7 \%) 4850 \mathrm{BC}\end{array}$ \\
\hline
\end{tabular}

a $1 \sigma$ uncertainty.

b The ${ }^{14} \mathrm{C}$ age calibration was performed with the INTCAL98 calibration curve (Stuiver et al. 1998).

$c$ One individual can be represented by more find inventory numbers.

$\mathrm{d}$ A single find inventory number may include more than one individual.

${ }^{\mathrm{e}}$ n.a. $=$ not available.

heim data. We concluded that this sample was probably contaminated by a consolidant. The $\chi^{2}$ test of the reduced data set (7.5 compared to a value of 11.1 at $5 \mathrm{df}$ for the rejection of the $\mathrm{H}_{0}$ at the $5 \%$ significance level) also indicates that these samples may be of the same age.

In the calculation of the weighted mean, the fact that several samples were measured in 1 measurement run was taken into account. In routine ${ }^{14} \mathrm{C}$ measurement at VERA, about 30 sputter targets of "unknowns" are mounted in a target wheel together with a set of ${ }^{14} \mathrm{C}$ standards and 1 blank sample ("dead" carbon) which were produced at the same time. The ${ }^{14} \mathrm{C} /{ }^{12} \mathrm{C}$ ratio determined for each of the measured unknowns present in 1 wheel is corrected with the same blank value and normalized to the same set of standards. Therefore, in the evaluation of the standard deviation of the weighted mean value of all ${ }^{14} \mathrm{C}$ ages, correlated uncertainties had to be taken into account. (For details of the routine evaluation procedures, see Steier et al., these proceedings.) The results of the combination of the data and the calibration of the thus derived ${ }^{14} \mathrm{C}$ ages are displayed in Figure 4. The respective $\chi^{2}$ value of each data set is also indicated in the plot. 
Table $2{ }^{14} \mathrm{C}$ data (rounded off according to Stuiver and Pollach 1977) of the Early Neolithic bone samples from Talheim and Herxheim measured at VERA and at the Academy of Science at Heidelberg.

\begin{tabular}{|c|c|c|c|c|}
\hline${ }^{14} \mathrm{C}$ lab nr & $\begin{array}{l}\text { Find inventory } \mathrm{nr} \\
\text { sample material, location }\end{array}$ & $\begin{array}{l}\delta^{13} \mathrm{C}^{\mathrm{a}} \\
{[\% \mathrm{o}]}\end{array}$ & $\begin{array}{l}{ }^{14} \mathrm{C} \text { age }{ }^{\mathrm{a}} \\
{[\mathrm{BP}]}\end{array}$ & $\begin{array}{l}\text { Calibrated time range }{ }^{b} \\
2 \sigma \text { confidence interval }\end{array}$ \\
\hline VERA-2021 & $\begin{array}{l}\text { SK16, human bone, } \\
\text { Talheim }\end{array}$ & $-22.9 \pm 0.5$ & $5930 \pm 35$ & $\begin{array}{l}4910 \mathrm{BC}(7.5 \%) 4870 \mathrm{BC} \\
4860 \mathrm{BC}(87.9 \%) 4710 \mathrm{BC}\end{array}$ \\
\hline VERA-2022 & $\begin{array}{l}\text { 83/1, human bone, } \\
\text { Talheim }\end{array}$ & $-21.9 \pm 0.5$ & $6130 \pm 35$ & $\begin{array}{l}5230 \mathrm{BC}(18.4 \%) 5160 \mathrm{BC} \\
5150 \mathrm{BC}(75.7 \%) 4940 \mathrm{BC} \\
4870 \mathrm{BC}(1.2 \%) 4860 \mathrm{BC}\end{array}$ \\
\hline VERA-2023 & $\begin{array}{l}\text { 83/10, human bone, } \\
\text { Talheim }\end{array}$ & $-22.0 \pm 0.4$ & $6085 \pm 30$ & $\begin{array}{l}5200 \mathrm{BC}(1.7 \%) 5180 \mathrm{BC} \\
5070 \mathrm{BC}(85.1 \%) 4900 \mathrm{BC} \\
4890 \mathrm{BC}(8.6 \%) 4850 \mathrm{BC}\end{array}$ \\
\hline VERA-2025 & $\begin{array}{l}\text { SK22, human bone, } \\
\text { Talheim }\end{array}$ & $-21.5 \pm 0.5$ & $6015 \pm 35$ & $5000 \mathrm{BC}(95.4 \%) 4780 \mathrm{BC}$ \\
\hline VERA-2026 & $\begin{array}{l}\text { 83/13, human bone, } \\
\text { Talheim }\end{array}$ & $-21.4 \pm 0.3$ & $6095 \pm 35$ & $\begin{array}{l}5210 \mathrm{BC}(5.6 \%) 5170 \mathrm{BC} \\
5140 \mathrm{BC}(1.2 \%) 5120 \mathrm{BC} \\
5080 \mathrm{BC}(82.3 \%) 4900 \mathrm{BC} \\
4890 \mathrm{BC}(6.3 \%) 4850 \mathrm{BC}\end{array}$ \\
\hline VERA-2046 & $\begin{array}{l}\text { SK21?, human bone, } \\
\text { Talheim }\end{array}$ & $-22.7 \pm 1.1$ & $6115 \pm 35$ & $\begin{array}{l}5210 \mathrm{BC}(11.8 \%) 5170 \mathrm{BC} \\
5150 \mathrm{BC}(5.6 \%) 5110 \mathrm{BC} \\
5100 \mathrm{BC}(75.0 \%) 4910 \mathrm{BC} \\
4880 \mathrm{BC}(2.9 \%) 4850 \mathrm{BC}\end{array}$ \\
\hline VERA-2047 & $\begin{array}{l}\text { 83/19, human bone, } \\
\text { Talheim }\end{array}$ & $-21.6 \pm 0.9$ & $6140 \pm 40$ & $\begin{array}{l}5260 \mathrm{BC}(22.9 \%) 5160 \mathrm{BC} \\
5150 \mathrm{BC}(72.5 \%) 4940 \mathrm{BC}\end{array}$ \\
\hline HD $8606-8827$ & $\begin{array}{l}\text { SK4, human bone, } \\
\text { Talheim }\end{array}$ & $-21.18^{c}$ & $5960 \pm 80$ & $\begin{array}{l}5060 \mathrm{BC}(94.3 \%) 4670 \mathrm{BC} \\
4640 \mathrm{BC}(1.1 \%) 4610 \mathrm{BC}\end{array}$ \\
\hline HD $8607-8828$ & $\begin{array}{l}\text { SK14, human bone, } \\
\text { Talheim }\end{array}$ & $-20.59^{c}$ & $6045 \pm 80$ & $5250 \mathrm{BC}(95.4 \%) 4700 \mathrm{BC}$ \\
\hline VERA-1826 & $\begin{array}{l}\text { E96/102 281-14-6 } \\
\text { human bone, Herxheim }\end{array}$ & $-19.1 \pm 1.3$ & $6145 \pm 35$ & $\begin{array}{l}5260 \mathrm{BC}(25.0 \%) 5160 \mathrm{BC} \\
5150 \mathrm{BC}(70.4 \%) 4940 \mathrm{BC}\end{array}$ \\
\hline VERA-1827 & $\begin{array}{l}\text { E96/102 281-117-4 } \\
\text { human bone, Herxheim }\end{array}$ & $-20.1 \pm 1.2$ & $6165 \pm 40$ & $5260 \mathrm{BC}(95.4 \%) 4960 \mathrm{BC}$ \\
\hline VERA-1828 & $\begin{array}{l}\text { E96/102 282-7-6 } \\
\text { human bone, Herxheim }\end{array}$ & $-20.7 \pm 1.3$ & $6190 \pm 30$ & $5260 \mathrm{BC}(95.4 \%) 5040 \mathrm{BC}$ \\
\hline VERA-1830 & $\begin{array}{l}\text { E96/102 296-16 } \\
\text { human bone, Herxheim }\end{array}$ & $-22.5 \pm 1.3$ & $6195 \pm 35$ & $5290 \mathrm{BC}(95.4 \%) 5040 \mathrm{BC}$ \\
\hline
\end{tabular}

a $1 \sigma$ uncertainty.

${ }^{b}$ The ${ }^{14} \mathrm{C}$ age calibration was performed with the INTCAL98 calibration curve (Stuiver et al. 1998).

c $1 \sigma$ standard deviation smaller than $0.03 \%$.

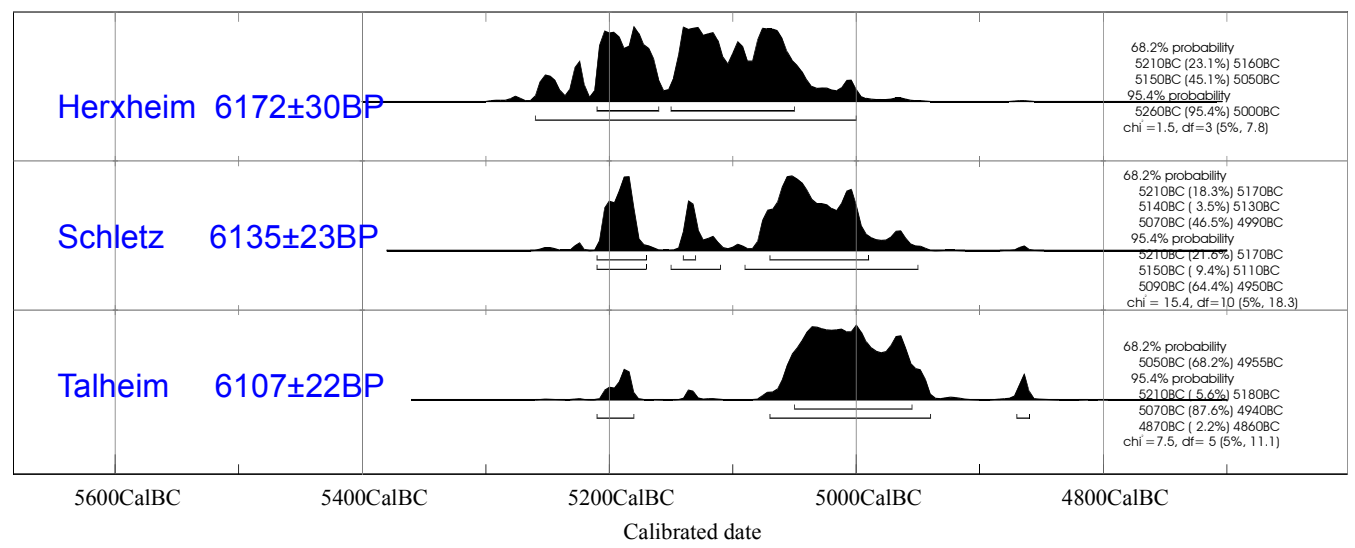

Figure 4 Calibration of the mean ${ }^{14} \mathrm{C}$ age values from the 3 sites investigated in this study. The results of the $\chi^{2}$ are also listed. 


\section{DISCUSSION}

Although it is known that bone collagen of humans shows a variable turnover time which depends on the biological age of the individual (Wild et al. 1998), it is not expected to detect such an effect in archaeological bone samples with the precision presently achieved in $\mathrm{AMS}{ }^{14} \mathrm{C}$ determinations. It must also be noted that variations in the ${ }^{14} \mathrm{C}$ age must be very small due to the relatively short lifetime of people from this time period; for instance, the mean lifespan of the Neolithic Talheim population was estimated to be about $24 \mathrm{yr}$ (Wahl and König 1987). Thus, it was assumed that the $\chi^{2}$ test of data from human bone samples should not fail if all the individuals died at the same time, because such samples would be of the same ${ }^{14} \mathrm{C}$ age. This could be shown for the data of each of the LBK sites investigated in this study. The $\chi^{2}$ tests show no indication that these data sets include samples of different age. Therefore, according to our results, the massacre theory seems plausible for all 3 sites. But once again, it should be noted that the complex Herxheim site is not directly comparable to the others and a different interpretation is under discussion (see above).

From the calibrated date ranges shown in Figure 4, it can be deduced that the events at Talheim and at Schletz may have been contemporary. According to the calibration results, the event at Herxheim may have taken place earlier than the 2 other sites, although the possibility that the Herxheim event is coeval with the others cannot be fully excluded.

These results induce further questions about the reasons for increased violence at the end of the LBK period. Obvious aggression is documented by the appearance of fortification ditches at settlements from this time. Three reasons are discussed as possible causes for inter-human attacks and massacres: a) these events were the consequence of the breakdown of local economic systems, leading to local skirmishes between neighbors in isolated regions in Europe; b) these events were triggered by a more general disturbance (e.g. climate) affecting a larger area of Europe; and c) the massacres were caused by a wave of migration that overran Central Europe and may also have been triggered by climatic changes (see Teschler-Nicola et al. 1999).

\section{CONCLUSION}

The ${ }^{14} \mathrm{C}$ data of the Early Neolithic site at Schletz described above support the massacre theory derived from the osteological investigation of the human remains. No younger Neolithic material was found at this site, which suggests that this massacre was the end of the Neolithic settlement period. For the 2 German sites, the ${ }^{14} \mathrm{C}$ data indicate that the human remains may be coeval, and a massacre theory seems to be possible for these sites, although for the Herxheim site another explanation for the atypical burial of the Neolithic human remains is under discussion.

\section{ACKNOWLEDGEMENTS}

The investigation of the Schletz samples was performed in the course of the research project P12253-PHY "Absolute Chronology for Early Civilizations in Austria and Central Europe using ${ }^{14} \mathrm{C}$ Dating with Accelerator Mass Spectrometry" funded by the Austrian Science Fund. We wish to thank Harald Humberger and Martin Janner for their help in sample preparation.

\section{REFERENCES}

Geyh M, Schleicher H. 1990. Absolute Age Determination. Physical and Chemical Dating Methods and Their Application. Berlin-Heidelberg, New York: Springer-Verlag.

Häußer A, editor. 1998. Krieg oder Frieden? Herxheim vor 7000 Jahren. Exhibition catalog printed in Oden- wald, Bellheim, Germany.

Orschiedt J. 2003. Ein überlebtes, mehrfaches Schädeltrauma aus dem frühen Neolithikum. In: Abstracts of the Workshop: Frühe Spuren der Gewalt-Schädelverletzungen und Wundversorgung an prähistorischen Menschenresten aus interdisziplinärer Sicht, 
28.11.2003-30.11.2003. Rostock-Warnemünde. p 910.

Petrasch J. 1999. Mord und Krieg in der Bandkeramik. Archäologisches Korrespondenzblatt 29:505-16.

Steier P, Dellinger F, Kutschera W, Rom W, Wild EM. 2003. Pushing the precision of ${ }^{14} \mathrm{C}$ measurements with AMS. Radiocarbon, these proceedings.

Stuiver M, Polach HA. 1977. Discussion: reporting of ${ }^{14} \mathrm{C}$ data. Radiocarbon 19(3):355-63.

Stuiver M, Reimer PJ, Bard E, Beck JW, Burr GS, Hughen KA, Kromer B, McCormac G, van der Plicht J, Spurk M. 1998. INTCAL98 radiocarbon age calibration, 24,000-0 cal BP. Radiocarbon 40(3):104183.

Teschler-Nicola M, Gerold F, Bujatti-Narbeshuber M, Prohaska T, Latkoczy Ch, Stingeder G, Watkins M. 1999. Evidence of genocide $7000 \mathrm{BP}-$ Neolithic paradigm and geoclimatic reality. Collegium Antropologicum 23:437-50.

Wahl J, König HG. 1987. Anthropologisch-Traumatologische Untersuchung der menschlichen Skelettreste aus dem Bandkeramischen Massengrab bei Talheim, Kreis Heilbronn. Fundberichte Baden-Württemberg 12:65-193.

Wild EM, Stadler P, Bondá MR, Draxler S, Friesinger H, Kutschera W, Priller A, Rom W, Ruttkay E, Steier P. 2001. New chronological frame for the Young Neolithic Baden culture in Central Europe (4th millenium BC). Proceedings of the 17th International Radiocarbon Conference. Radiocarbon 43(2B): 1057-64.

Wild E, Golser R, Hille P, Kutschera W, Priller A, Puchegger S, Rom W, Steier P, Vycudilik W. 1998. First ${ }^{14} \mathrm{C}$ results from archaeological and forensic studies at the Vienna Environmental Research Accelerator. Radiocarbon 40(1):273-81.

Windl H, editor. 1996. Rätsel um Gewalt und Tod vor 7000 Jahren. Katalog des NÖ Landesmuseums. Asparn a.d. Zaya, Austria.

Windl H. 2001. Erdwerke der Linearbandkeramik in Asparn an der Zaya/Schletz, Niederösterreich. Preistoria Alpina 37:137-44. 